Dept. of Pathology and Clinical Pathology,

Fac. of Vet. Med., Assiut University, Assiut, Egypt.

\title{
EVALUATION OF LEAD TOXICITY ON REPRODUCTION USING THE FERTILITY TEST IN RATS
}

(With 3 Tables and 3 Figures)

\author{
By \\ K.M.A. HASSANEIN; A.Z. MAHMOUD \\ and MANAL M. SAYED*
}

*Animal Health Research Institute Assiut Lab.

(Received at 15/9/2010)

\section{تقييم سمية الرصاص على التكاثر باستخدام اختبار الخصوبة فى الجرذان

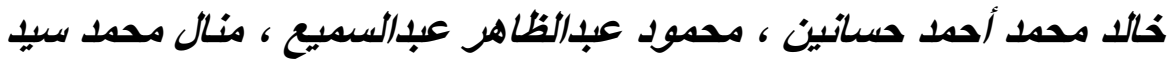

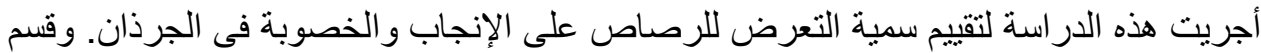

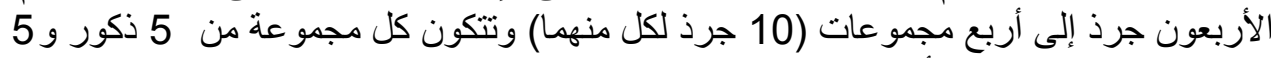

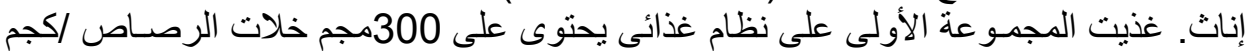

عليقة. المجمو عة الثانية ، كانت تتغذى إناث الجرذان الته على على نظام غذائى يحتوى على على خلات

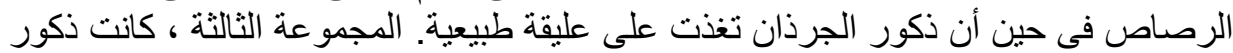

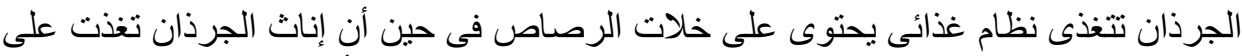

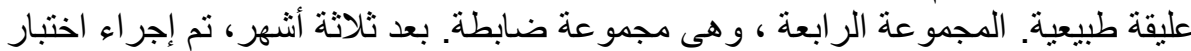

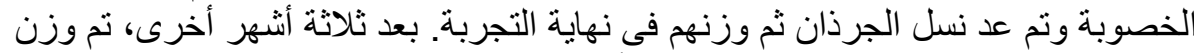

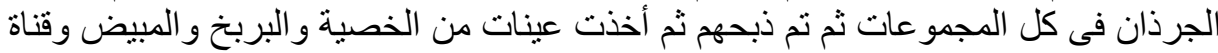

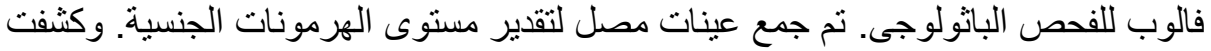

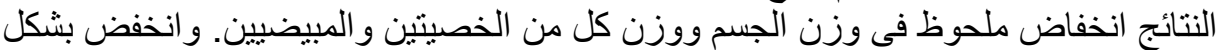

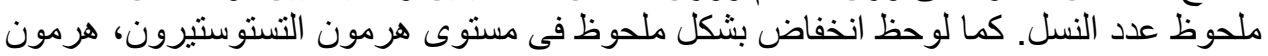

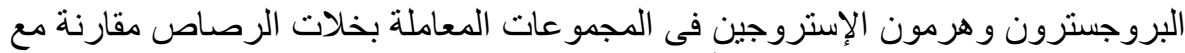

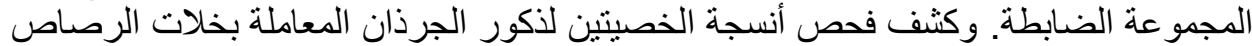

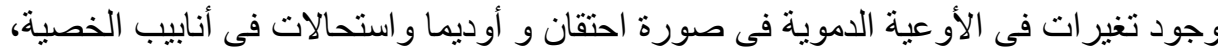

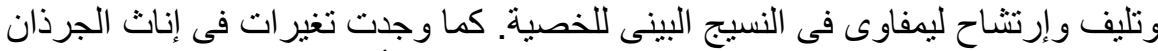

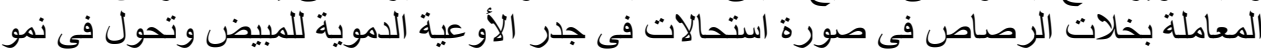

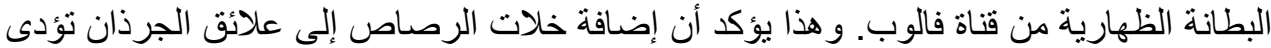

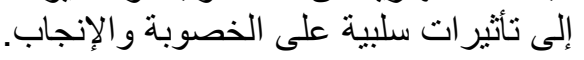

\section{SUMMARY}

The present study was conducted to evaluate the toxicity of lead $(\mathrm{Pb})$ on reproduction and fertility in Sprague-Dawley rats. Forty rats were divided into four groups (10 rats each) and every group contained 5 male and 5 
female rats. Group (1), male and female rats were fed on a diet containing $300 \mathrm{mg}$ lead acetate/kg diet. Group (2), the female rats were fed on a diet containing lead acetate while the male rats fed on normal diet. Group (3), the male rats were fed on a diet containing lead acetate while the female rats fed on normal diet. Group (4), served as control. After three months, the fertility test was made and the offspring were counted then weighted at the end of experiment. Three months later, rats in all groups were weighted then sacrificed and specimens from testes, epididymis, ovaries and fallopian tubes were taken for histopathology. Serum samples were collected for determination of sex hormones. In lead acetate treated groups there were a significant decrease in the total body weight as well as testes and ovaries. The number of offspring was significantly decreased. The mean levels of testosterone, progesterone and estrogen in lead acetate treated group were significantly decreased when compared with control group. Histopathological examination of the testes of male rats treated with lead acetate revealed vascular changes in the form of congestion and edema, testicular degeneration, fibrosis and lymphocytic infiltration in the interstitial tissue. Lesions in female rats treated with lead acetate revealed vascular and degenerative changes in the ovaries and metaplasia of the epithelial lining of the fallopian tubes. It was concluded that lead toxicity induced adverse effects on the fertility and reproduction of rats.

Keywords: Fertility, histopathology, lead acetate, rats and reproduction.

\section{INTRODUCTION}

The toxicity of lead has been known for millennia and has become the most complete and useful model for industrial toxicology studies (Silbergeld, 1990). Lead is a heavy soft metal, occurs in nature as an oxide or salts. Lead is a ubiquitous environmental and industrial pollutant that has been detected in every facet of environmental and biological systems. Lead can be found in water pipes, insecticides, lining of equipment where corrosion resistance and pliability are required, in petroleum refining, in construction, bullets of gun, $\mathrm{x}$-ray and atomic radiation protection and is a major industrial by product. The manipulation of lead for these uses has caused lead contamination of air, dust and soil (Bokara et al., 2008). Lead toxicity induced hematological, gastrointestinal and neurological dysfunction in mammals (Lockitch, 1993). Moreover, lead toxicity cause changes in the nervous system, cardiovascular, reproductive, and immune systems (Apostoli et al., 1998 and Taupeau et al., 2001).

Lead can delay sexual maturation; however the mechanism and critical time of insult are not clearly defined (Dearth et al., 2002). Exposure 
to lead acetate in drinking water resulted in a decrease in basal gonadotropin-stimulated testosterone production (Sokol et al., 1985) and a decrease in serum testosterone (Hsu et al., 1998; Queiroz and Waissmann, 2006). Treatment of males with lead acetate caused testicular atrophy, cellular degeneration, interstitial cell necrosis and suppression of spermatogenesis. In addition, it decreases serum testosterone. All these effects were time and dose dependent (Mousa and Okasha, 1998).

In adult females, lead salts caused inhibition of follicle stimulating hormone secretion and also have a direct effect on ovarian function, causing a reduction in progesterone secretion. This effectively leads to uterine hypotrophy. A direct effect on the uterus also may occur, since lead inhibits implantation, probably by inhibiting the induction of uterine estrogen receptors (Khan and Satyaswaroop, 1995). Exposure to lead neonatally resulted in delayed puberty (Mattison and Thomford, 1989). In animals treated with lead, atrophy of the ovary, reduction of serum progesterone concentration and alteration of uterine hormonal receptors have been observed. These toxicities may result from different effects along the hypothalamic-pituitary-ovarian-endometrial axis (Haschek, 1989).

The purpose of this study was to investigate the effects of lead poisoning of rats on the reproduction by using the histopathology, sex hormones and fertility test.

\section{MATERIALS and METHODS}

Animals: Forty Sprague-Dawley rats aged 2-3 months and weighing 150$170 \mathrm{~g}$ were obtained from Helwan Farm for Laboratory Animal Breading, Cairo, Egypt. The animals were housed 5 per cage with wood shavings, and were maintained under a controlled environment with temperature at $23 \pm 2^{\circ} \mathrm{C}$, relative humidity at $55 \pm 5 \%$, and a $12 \mathrm{hrs} / 12 \mathrm{hrs}$ light/dark cycle throughout the experiment.

\section{Chemicals:}

1- Lead acetate was obtained from Sigma-Aldrich, USA.

2- Testosterone, progesterone and estrogen enzyme immunoassay kits were obtained from BioCheck, Inc. 323 Vintage Park Dr Foster City, CA 94404. USA.

\section{Experimental design:}

Rats were divided into four groups (10 rats each). Every group contained 5 male and 5 female rats in a two separate cages. In the first group, male and female rats fed on a diet contain $300 \mathrm{mg}$ lead acetate $/ \mathrm{kg}$ diet (Haneef et al., 1995). In the second group, the female rats fed on a diet contain lead acetate $(300 \mathrm{mg} / \mathrm{kg}$ diet) while the male rats fed on normal 
diet. In the Third group, the male rats fed on a diet contain lead acetate (300 mg $/ \mathrm{kg}$ diet) while the female rats fed on normal diet. In the fourth group, male and female rats fed on a normal diet and served as control. This part of experiment was done for three months. After that, the fertility test was made by mating between males and females in the same group (by putting one male rat with the females in each group in one cage at the time of mating). Pregnant rats were isolated until parturition. The offspring were counted and weighted from each female in all experimental and control groups. This part of experimentation was extending for another three months with the same doses of lead acetate in the diet of rats. Rats in all groups were weighted at the end of experiment.

\section{Sampling:}

At the end of experiment, rats were sacrificed and their genital organs were weighted. Specimens from testes, epididymis, ovaries and fallopian tubes were taken for histopathological examination. Serum samples were collected for determination of testosterone, estrogen and progesterone.

\section{Histopathology}

Specimens were fixed in $10 \%$ neutral buffered formalin, dehydrated in a graded alcohol series, cleared with methyl benzoate and embedded in paraffin wax. Sections of $5 \mu \mathrm{m}$ were cut and stained with haematoxylin/eosin and Van Gieson stain for light microscopic examination (Bancroft et al., 1996). Stained sections were examined by light microscope and photographed using digital camera.

\section{Determination of sex hormone:}

Testosterone, progesterone and estradiol (E2) hormones measured by quantitative enzyme immunoassay using commercially formulated kits. The enzymes were detected by color and the absorbance was measured at $450 \mathrm{~nm}$ by ELIZA reader.

\section{Statistical analysis:}

Statistical analysis was carried out by analysis of variance (ANOVA) and the results were compared using student $t$ test. All statistical tests were performed using Graphpad Software Package.

\section{RESULTS}

The rat's administrated lead acetate showed emaciation, weakness dullness and paleness of the mucous membranes. In lead acetate exposed rats there were extremely significant decrease in total body weight and genital tract weight in male rats $(\mathrm{P}<0.001)$ when compared with control group. The female rats exposed to lead acetate showed significant decrease in the total body weight (P 0.01 to 0.05 ) and very significant decrease of 
genital tract weight (P 0.001 to 0.01 ) when compared with control group. It was also observed that the mean weight of testes and ovaries was very significant decrease (P 0.001 to 0.01 ) when compared with control group (Table 1). The total number of offspring was very significantly decreased in group 1,2 and 3 when compared with control group. The genital tract weight of offspring was extremely significant decrease in group 2 when compared with other groups. Also, it was observed that their testes weights were decreased significantly when compared with control group. While, there was no significant difference $(\mathrm{P}>0.05)$ of ovaries weight of offspring in all groups when compared with control group (Table. 2)

Table 1: Effect of lead acetate on body weight, genital tract weight, testes and ovaries weight (gm).

\begin{tabular}{|c|c|c|c|c|c|c|}
\hline Groups & \multicolumn{2}{|c|}{$\begin{array}{c}\text { Total body weight } \\
(\mathrm{gm})\end{array}$} & \multicolumn{2}{c|}{$\begin{array}{c}\text { Genital tract weight } \\
(\mathrm{gm})\end{array}$} & $\begin{array}{c}\text { Testes } \\
(\mathrm{gm})\end{array}$ & $\begin{array}{c}\text { Ovaries } \\
(\mathrm{gm})\end{array}$ \\
\hline & 0 & $q$ & 0 & 9 & & \\
\hline Group & $210 \pm$ & $159.80 \pm$ & $8.20 \pm$ & $0.9 \pm$ & $4.17 \pm$ & $0.14 \pm$ \\
$(1)$ & $4.47^{* * *}$ & $7.21^{*}$ & $0.26^{* * *}$ & $0.04^{* *}$ & $0.19^{* *}$ & $0.02^{* *}$ \\
\hline Group & $234 \pm 4.3$ & $157.40 \pm$ & $11.4 \pm$ & $0.7 \pm$ & $5.16 \pm$ & $0.09 \pm$ \\
$(2)$ & $\mathrm{ns}$ & $9.53^{*}$ & $0.43 \mathrm{~ns}$ & $0.003^{* * *}$ & $0.2 \mathrm{~ns}$ & $0.004^{* * *}$ \\
\hline Group & $191 \pm$ & $178.60 \pm$ & $8.72 \pm$ & $1.30 \pm$ & $3.96 \pm$ & $0.3 \pm$ \\
$(3)$ & $6.40^{* * *}$ & $2.1 \mathrm{~ns}$ & $0.28^{* * *}$ & $0.13 \mathrm{~ns}$ & $0.05^{* * *}$ & $0.06 \mathrm{~ns}$ \\
\hline Group & $246 \pm$ & $186 \pm$ & $11.4 \pm$ & $1.78 \pm$ & $6.02 \pm$ & $0.36 \pm$ \\
$(4)$ & 5.10 & 5.34 & 0.43 & 0.17 & 0.34 & 0.05 \\
\hline
\end{tabular}

Ns not significant $(\mathrm{P}>0.05),{ }^{*}$ Significant difference by t-test ( $\mathrm{P} 0.01$ to 0.05$)$, ** Very significant (P 0.001 to 0.01$)$, *** Extremely significant $(\mathrm{P}<0.001)$.

Table 2: Effect of lead acetate on fertility and the weight of genital tract, testes and ovaries of offspring.

\begin{tabular}{|c|c|c|c|c|c|}
\hline Groups & $\begin{array}{c}\text { Total } \\
\text { number of } \\
\text { offspring }\end{array}$ & \multicolumn{2}{|l|}{ Genital tract weight (gm) } & $\begin{array}{c}\text { Testes } \\
(\mathrm{gm})\end{array}$ & $\begin{array}{c}\text { Ovaries } \\
(\mathrm{gm})\end{array}$ \\
\hline & & 0 & 9 & & \\
\hline Group & $2.60 \pm$ & $5.30 \pm$ & $0.54 \pm$ & $2.50 \pm$ & $0.08 \pm$ \\
$(1)$ & $0.24 * *$ & $0.38 * *$ & $0.05 *$ & $0.18 * *$ & $0.004 \mathrm{~ns}$ \\
\hline Group & $2.20 \pm$ & $4.48 \pm$ & $0.36 \pm$ & $2.14 \pm$ & $0.074 \pm$ \\
$(2)$ & $0.20 * *$ & $0.21 * * *$ & $0.02 * * *$ & $0.16 * * *$ & $0.007 \mathrm{~ns}$ \\
\hline Group & $2.20 \pm$ & $5.38 \pm$ & $0.38 \pm$ & $2.56 \pm$ & $0.072 \pm$ \\
$(3)$ & $0.20 * *$ & $0.35 * *$ & $0.06 * *$ & $0.17 * *$ & $0.006 \mathrm{~ns}$ \\
\hline Group & $5.60 \pm$ & $7.68 \pm$ & $0.76 \pm$ & $3.70 \pm$ & $0.08 \pm$ \\
(4) & 0.68 & 0.33 & 0.05 & 0.16 & $0.007 \mathrm{~ns}$ \\
\hline
\end{tabular}

Ns not significant $(\mathrm{P}>0.05)$ * Significant difference by t-test ( $\mathrm{P} 0.01$ to 0.05$)$, $* *$ Very significant $(\mathrm{P} 0.001$ to 0.01$)$, *** Extremely significant $(\mathrm{P}<0.001)$. 


\section{Histopathology}

\section{Testicle and epididymis:}

Histopathological examination of HE-stained sections revealed that the treatment of male rats with lead acetate produced vascular and cellular changes. The vascular changes were congestion of the blood vessels with fibrinoid necrosis of its wall (Fig. 1A). Interstitial edema was observed in most cases and separation of leydig cells (Fig. 1B). Proliferation of fibrous connective tissue in the interstitium was also observed and confirmed by Van Gieson stain (Figs. 1E,F). The seminiferous tubules suffered from degenerative changes in the spermatocytes, their basement membranes were thickened and hyalinized (Fig. 1C). Testicular degeneration was confirmed by presence of multinucleated spermatid giant cells in the lumen of seminiferous tubules (Fig. 1D). Some seminiferous tubules were lined by sertoli cells and few spermatogonia (Fig. 2A). The interstitial tissue was heavily infiltrated with lymphocytes (Figs. 2B,C). Examination of the epididymis revealed degenerative changes in the epididymal tubules with interstitial edema (Fig. 2 D).

\section{Ovary and fallopian tube:}

Histopathological examination of ovaries of female rats treated with lead acetate demonstrated prominent vascular changes. The blood vessels showed congestion and fibrinoid necrosis of their walls. Some blood vessels were thrombosed with swelling of the endothelial lining (Figs. $3 \mathrm{~A}, \mathrm{~B})$. The primordial follicles showed degenerative changes. The nuclei revealed karyorehexis and karyolysis. Some follicular cells were desquamated (Fig. 3C). Examination of the fallopian tubes showed metaplasia of the lining epithelium (Fig. 3D).

\section{Determination of sex hormone:}

In male rats, it was observed that the mean level of testosterone in lead acetate treated group was extremely significantly decreased $(\mathrm{P}<0.001)$ when compared with control group. In female rats there was significant decrease in progesterone and estrogen levels in lead acetate treated group (p 0.01 to 0.05 ) when compared with control group (Table. 3 ).

Table 3: Serum levels of testosterone $(\mathrm{ng} / \mathrm{ml})$, progesterone $(\mathrm{ng} / \mathrm{ml})$ and estrogen $(\mathrm{pg} / \mathrm{ml})$ in rats treated with lead acetate in comparison with control group.

\begin{tabular}{|c|c|c|c|}
\hline Groups & $\begin{array}{c}\text { Testosterone } \\
(\mathrm{ng} / \mathrm{ml})\end{array}$ & $\begin{array}{c}\text { Progesterone } \\
(\mathrm{ng} / \mathrm{ml})\end{array}$ & $\begin{array}{c}\text { Estrogen } \\
(\mathrm{pg} / \mathrm{ml})\end{array}$ \\
\hline Group (1) & $0.7 \pm 0.25 * * *$ & $4.5 \pm 0.86 *$ & $25.15 \pm 3.30 *$ \\
\hline Group (4) & $2.66 \pm 0.17$ & $8.33 \pm 1.3$ & $44.29 \pm 6.47$ \\
\hline
\end{tabular}

* Significant difference by t-test (p 0.01 to 0.05 ).

$* * *$ Extremely significant $(\mathrm{P}<0.001)$. 
Fig.1
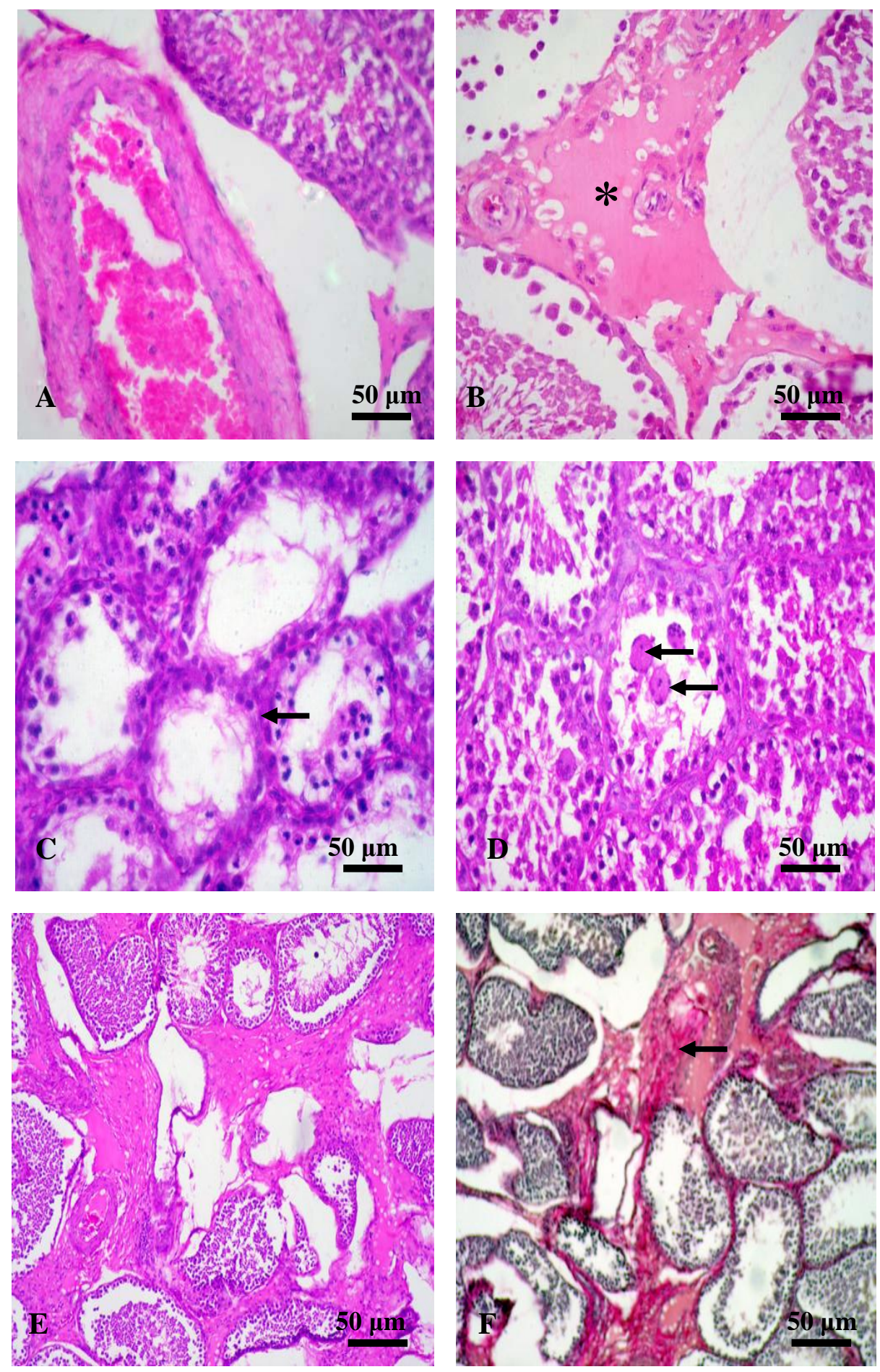
Fig. 2
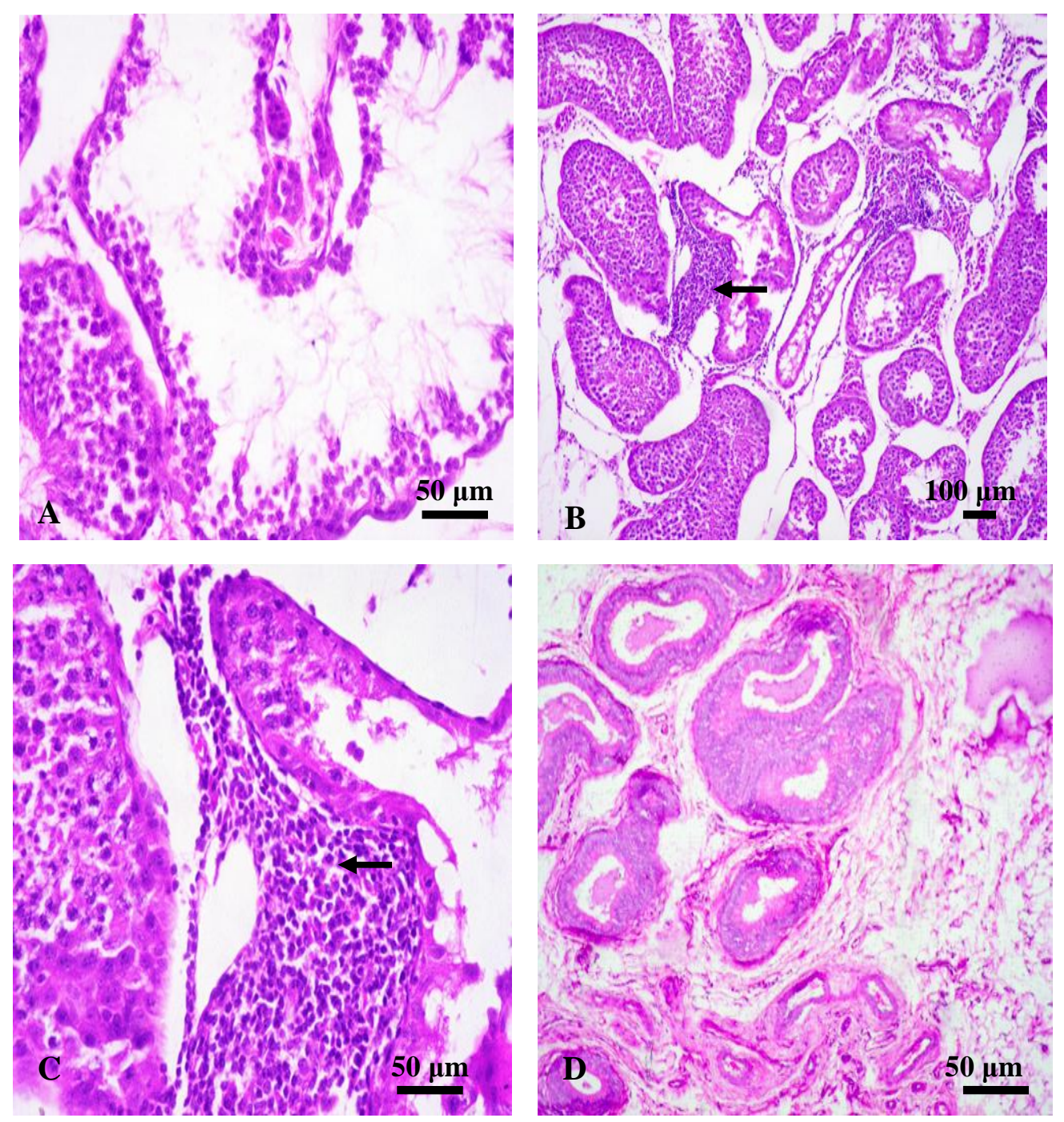
Fig. 3
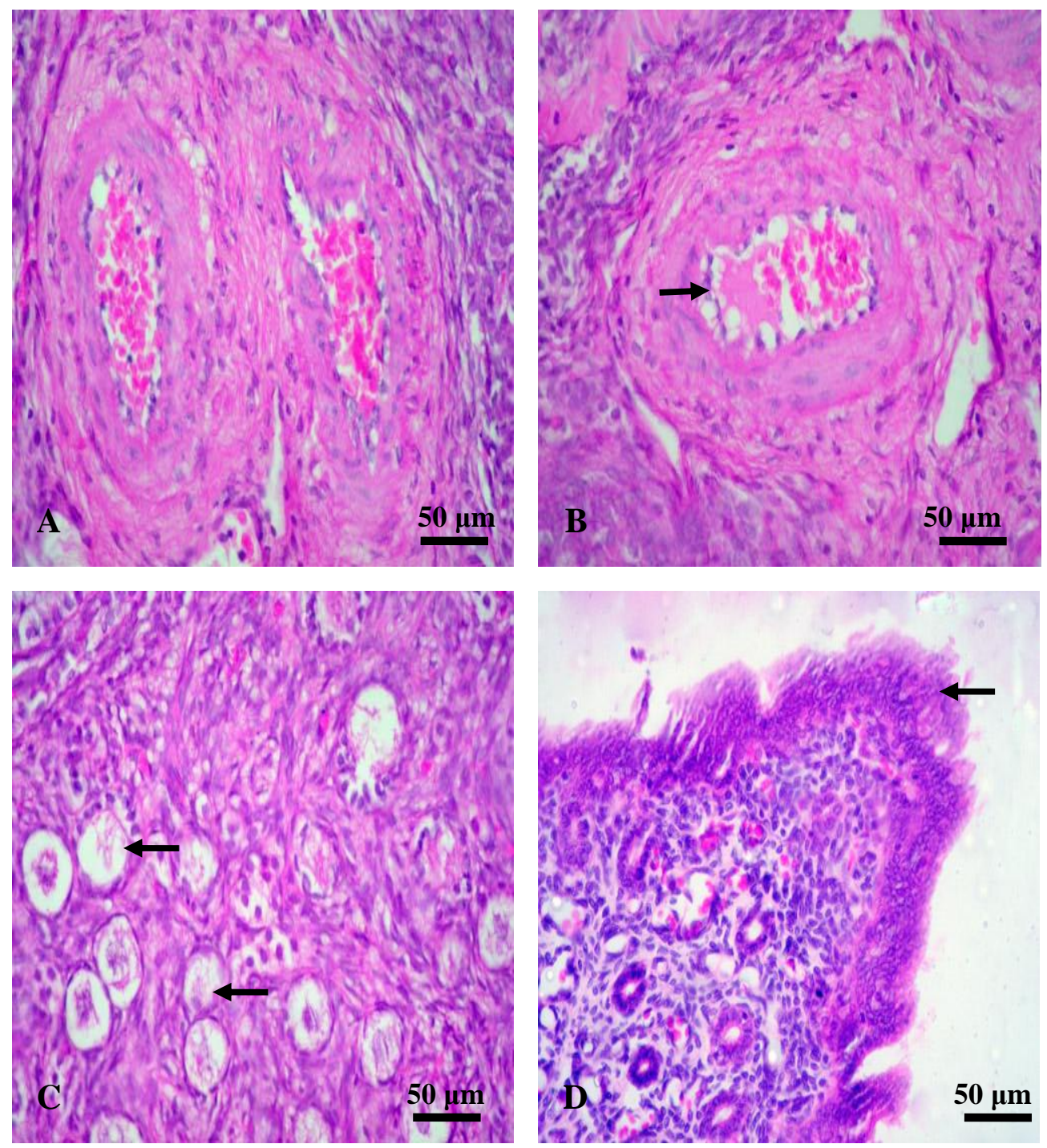


\section{LEGENDS OF FIGURES}

Fig. 1: Representative micrographs for histopathological findings in the testicle of rats after 6 months of treatment with lead acetate. (A) Congestion of the blood vessel with fibrinoid necrosis of its wall. (B) Edema of the interstitial tissue (asterisk). (C) Testicular degeneration and thickening of the basement membrane of seminiferous tubules (arrow). (D) Testicular degeneration with formation of spermatid giant cells (arrows). (E) Edema and proliferation of fibrous tissue in the interstitium. HE stain $(\mathrm{F})$ Fibrosis demonstrated by red colored collagen fiber (arrow). Van Gieson stain.

Fig. 2: Representative micrographs for histopathological findings in the testicle of rats and epididymis after 6 months of treatment with lead acetate. (A) seminiferous tubules lined only by sertoli cells and few spermatogonia (B,C) Presence of lymphocytic infiltration between the tubules (arrows) (D) Interstitial edema and degeneration of the epididymal tubules. HE stain.

Fig. 3: Representative micrographs for histopathological findings in the ovary and fallopian tube of rats after 6 months of treatment with lead acetate. (A,B) Ovarian blood vessls showing congestion, fibrinoid necrosis of the wall and desquamation of the endothelial lining (arrow). (C) Degenerative changes in the primordial follicles (arrows). (D) Epithelial metaplasia of the fallopian tube epithelium (arrow). HE stain.

\section{DISCUSSION}

Lead is one of the oldest known and most widely studied occupational and environmental toxins. Heavy metals such as lead, cadmium, arsenic and mercury can affect male reproductive functions including sperm counts; motility and morphology of spermatogenesis (Chia et al., 1992; Telisman et al., 2007 and Meeker et al., 2008).

In the present study, our results clearly demonstrated that exposure of adult male rats to lead acetate induced significant decrease in total body weight and weight of the testes. This reduction in weight of the testes accompanied by extremely significant decreased of the testosterone. Similarly, Wang et al. (2008) and Hamadouche et al. (2009) reported reduction in weight of sex glands and pituitary and reduction of testosterone in lead acetate exposed rats for 90 days. 
The histopathology of the testes of male rats treated with lead acetate for 6 months revealed vascular changes in the form of congestion and edema, testicular degeneration, fibrosis and lymphocytic infiltration in the interstitial tissue. These findings support the results from other reports which indicated that lead altered testis histology exhibited by disordered arrangement of germ cells and a decreased spermatogenic cell layer in the seminiferous tubules (Liu et al., 2008 and Hamadouche et al., 2009). On the other hand, Barratt et al. (1989) reported slight effect of lead on the germinal tissue which may be due to a protective effect of the blood-testes barrier.

In this study, epididymal changes were in the form of interstitial edema and degenerative changes. The results were coincident with the study conducted by Marchlewicz et al. (2004) and Hamadouche et al. (2009) that epididymal damage, including epithelial degeneration and edema in the interstitium. Epididymal changes may be an important factor in infertility caused by lead (Apostoli et al., 2000).

The female rats exposed to lead acetate revealed significant decrease in the total body weight and very significant decrease of genital tract weight when compared with control group. The levels of progesterone and estrogen were significantly decreased in lead acetate treated group. The histopathological examination revealed vascular and degenerative changes in the ovaries in the form of degeneration and desquamation of the primordial follicles and metaplasia of the epithelial lining of the fallopian tubes. In parallel, Taupeau et al. (2001) reported that low concentration of lead in the ovary resulted in dysfunction in the process of folliculogenesis with fewer primordial follicles. Moreover, Taupeau et al. (2003) found that lead toxicity induced damage of the primordial follicle. They suggested that increase production of androgen by theca cells may lead to decreased estrogen production by granulose cells which alter folliculogenesis. Ronis et al. (1996) stated that high level of lead concentration in blood (260-320 $\mathrm{mg} / \mathrm{dl}$ ) produced disruption of estrous cycle and significant suppression of plasma luteinizing hormone (LH) and estradiol.

In the present study, the total number of offspring and genital tract weight were significantly decreased in all treated groups when compared with control group. Also, testes weights were decreased significantly but there was no significant difference of ovaries weights of offspring in all treated group when compared with control group. Similarly, Donald et al. (1987) reported that administration of lead acetate $0.25 \%$ in drinking water did not affect the reproductive success. It decreased birth weight and retarded early development of offspring of treated dams. Also, Sant'Ana et al. (2001) stated that administration of $1 \% \mathrm{~Pb}$ decreased the testes 
weight of offspring. On the contrary, Coffigny et al. (1994) studied the effects of lead poisoning during pregnancy on female Sprague-Dawley rats that inhaled $5 \mathrm{mg}$ lead oxide for 13 days during gestation. No changes in the size of sex organs that did not perturb reproductive function in their male offspring.

It was concluded that lead toxicity induced adverse effects on the fertility and reproduction. In male rats, there was reduction of testes weight, reduction the level of testosterone and vascular and degenerative changes in the testes. In female rats, reduction in ovaries weight and the level of estrogen and progesterone were observed. Histopathology revealed prominent vascular and degenerative changes in the ovaries as there was reduction in the number of offspring.

\section{REFERENCES}

Apostoli, P.; Bellini, A.; Porru, S. and Bisati, L. (2000): The effect of lead on male fertility: a time to pregnancy (TTP) study. Am. J. Ind. Med., 38 (3): 310-315.

Apostoli, P.; Kiss, P.; Porru, S.; Bond, J.P. and Vanhoorne, M. (1998): Male reproductive toxicity of lead in animals and humans. Occup. Envioron. Med., 55: 364-374.

Bancroft, T.D.; Stevens, A. and Turner, D.R. (1996): Theory and practice of histological technique, 4th ed. Churchill, Livingstone, New York.

Barratt, C.; Davies, A. and Bansal, M. (1989): The effects of lead on the male rat reproductive system. Andrologia, 21: 161-166.

Bokara, K.K.; Brown, E.; McCormick, R.; Yallapragada, P.R.; Rajanna, S. and Bettaiya, $R$. (2008): Lead-induced increase in antioxidand enzymes and lipid peroxidation products in developing rat brain. Biometals., 21: 9-16.

Chia, S.E.; Ong, C.N.; Lee, S.T. and Tsakok, F.H. (1992): Blood concentrations of lead, cadmium, mercury, zinc, and copper and human semen parameters. Arch Androl., 29: 177-183.

Coffigny, H.; Thoreux-Manlay, A.; Pinon-Lataillade, G.; Masse, R. and Soufir, J.C. (1994): Effects of lead poisoning of rats during pregnancy on the reproductive system and fertility of other offspring. Hum. Exp. Toxicol., 13 (4): 241-246.

Dearth, F.K.; Hiney, J.K.; Srivastava, V.; Burdick, S.B.; Bratton, G.R. and Dees, W.L. (2002): Effects of lead (Pb) exposure during gestation and lactation on female pubertal development in the rat. Reprod. Toxicol., 16(4): 343-352. 
Donald, J.M.; Cutler, M.G. and Moore, M.R. (1987): Effects of lead in the laboratory mouse. Development and social behavior after lifelong exposure to 12 micronM lead in drinking fluid. Neuropharmacology, 26(4): 341-349.

Hamadouche, A.N.; Slimani, M.; Merad-Boudia, B. and Zaoui, C. (2009): Reproductive Toxicity of Lead Acetate in Adult Male Rats. American Journal of Scientific Research, 3: 38-50.

Haneef, S.S.; Kalicharan and Dwivedi, S.K. (1995): The effect of concurrent lead and cadmium on cell-mediated immune response in goats. Vet. Hum. Toxicol., 37(5): 428-429.

Haschek, J.A. (1989): Metal toxicity in a Guide to General Toxicology, $2^{\text {nd }}$ ed. Marquis J.A Ed. Karger, New York, pp. 179-189.

Hsu, P.C.; Hsu, C.C.; Liu, M.Y.; Chen, L.Y. and Guo, Y.L. (1998): Leadinduced changes in spermatozoa function and metabolism. J. Toxicol. Environ. Health, 55: 45-64.

Khan, F.S. and Satyaswaroop, P.G. (1995): Toxic effects of chemical and drugs on the sex accessory organs in the non-pregnant female. In: Reproductive Toxicology, second edition, edited by Witsorch, R.J.; Raven Press, Ltd, New York pp.159-173.

Liu, H.; Niu, R.; Wang, J.; He, Y.; Wang, J. and China, Shanxi. (2008): Changes caused by fluoride and lead in energy metabolic enzyme activities in the reproductive system of male offspring rats. Research Report Fluoride, 41 (3): 184-191.

Lockitch, G. (1993): Perspectives on lead toxicity. Clin. Biochem., 26(5): 371-381.

Marchlewicz, M.; Michalska, T. and Wiszniewska, B. (2004): Detection of lead-induced oxidative stress in the rat epididymis by chemiluminescence. Chemosphere, 57: 1553-1562.

Mattison, D.R. and Thomford, P.J. (1989): Mechanisms of action of reproductive toxicants. In: Working, P.K.ed, Toxicology of the male and female reproductive systems. New York: Hemisphere Publishing Corporation, pp. 101-129.

Meeker, J.D.; Rossano, M.G.; Protas, B.; Diamond, M.P.; Puscheck, E.; Daly, D.; Paneth, N. and Wirth, J.J. (2008): Cadmium, lead, and other metals in relation to semen quality: human evidence for Molybdenum as a male reproductive toxicant. Envron Health Persp., 116: 1473-1479.

Mousa, S.A. and Okasha, S. (1998): Effect of chronic lead exposure on immunoreactive luteinizing hormone, follicle stimulating hormone and growth hormone in the anterior pituitary and serum 
luteinizing hormone level in adult male albino rats. J. Egypt. Ger. Soc. Zool., 27(A): 199-216.

Queiroz, E.K.R. and Waissmann, W. (2006): Occupational exposure and effects on the male reproductive system. Cad. Saúde Pública, Rio de Janeiro, 22(3): 485-493.

Ronis, M.J.; Badger, T.M.; Roberson, P.K. and Shaikh, F. (1996): Reproductive toxicity and growth effects in rats exposed to lead at different periods during development. Toxicol. Appl. Pharmacol., 136: 361-371.

Sant'Ana, M.A.; Spinosa, H.S.; Florio, J.C.; Bernardi, M.M.; Oliveiro, C.A.; Sarkis, J.E. and Kakazu, M.H. (2001): Role of early GnRH administration in sexual behavior disorders of rat pups perinatally exposed to lead. Neurotoxicol. Toeratol., 23(2): 203-312.

Silbergeld, E.K. (1990): Towards the twenty-first century: lessons from lead and lessons yet to learn. Environ. Health Perspect., 86: 191-196.

Sokol, R.Z.; Madding, C.E. and Swerdloff, R.S. (1985): Lead toxicity and hypothalamic-pituitary-testicular axis. Biol. Reprod., 33:722-728.

Taupeau, C.; Poupon, J.; Nome, F. and Lefevre, B. (2001): Lead accumulation in the mouse ovary after treatment-induced follicular atresia. Reprod. Toxicol., 15(4): 385-391.

Taupeau, C.; Poupon, J.; Treton, D.; Broose, A.; Richard, Y. and Machelon, V. (2003): Lead reduced messenger RNA and protein levels of cytochrome P450 aromatase and estrogen receptor. Biol. Reprod., 68: 1982-1988.

Telisman, S.; Colak, B.; Pizent, A.; Jurasovic, J. and Cvitkovic, P. (2007): Reproductive toxicity of low-level lead exposure in men. Environ. res., 105: 256-266.

Wang, L.; Xun, P.; Zhao, Y.; Wang, X.; Qian, L. and Chen, F. (2008): Effects of lead exposure on sperm concentrations and testes weight in male rats: a meta-regression analysis. Toxicol. Environ. Healh., 71 (7): 454-63. 